\title{
Nutritional treatment of genome instability: a paradigm shift in disease prevention and in the setting of recommended dietary allowances
}

\author{
Michael Fenech \\ Cooperative Research Centre for Diagnostics, Genome Stability Project, CSIRO Health Sciences and Nutrition, \\ PO Box 10041, Adelaide BC, SA 5000, Australia
}

\begin{abstract}
The link between genome instability and adverse health outcomes during the various stages of life, such as infertility, fetal development and cancer, is briefly reviewed against a background of evidence indicating that genome instability, in the absence of overt exposure to genotoxins, is itself a sensitive marker of nutritional deficiency. The latter is illustrated with cross-sectional and dietary intervention data obtained using the micronucleus assay, an efficient biomarker for diagnosing genome instability and nutritional deficiency. The concept of recommended dietary allowances for genome stability and how this could be achieved is discussed together with the emerging field of nutritional genomics for genome stability. The review concludes with a vision for a disease-prevention strategy based on the diagnosis and nutritional treatment of genome instability, i.e. 'Genome Health Clinics'.
\end{abstract}

DNA damage: Genome stability: Micronutrients: Nutritional genomics: Recommended dietary allowances

\section{Introduction}

The central role of the genetic code in determining health outcomes such as developmental defects and degenerative diseases such as cancer is well established. In addition it is evident that DNA metabolism and repair is dependent on a wide variety of dietary factors that act as cofactors or substrates in these fundamental metabolic pathways (Ames, 2001; Fenech \& Ferguson, 2001; Ames \& Wakimoto, 2002). The DNA inherited from our parents is continuously under threat of major mutations from conception onwards by a variety of mechanisms, which include point mutation, base modification due to reactive molecules such as the hydroxyl radical, chromosome breakage and rearrangement, chromosome loss or gain, gene silencing due to inappropriate methylation of $\mathrm{CpG}$ at promoter sequences, activation of parasitic DNA expression due to reduced methylation of $\mathrm{CpG}$ as well as accelerated telomere shortening (Fenech \& Ferguson, 2001). It is true to say that all of the above mechanisms of genome damage occur spontaneously due to the effects of endogenously generated mutagens or due to deficiency in cofactors required for DNA metabolism and repair. However, it is also true that genetic defects in DNA metabolism and repair, the latter involving more than 100 genes in man (Lindahl \& Wood, 1999; Thompson \& Schild, 2002), are also a key factor. While much has been learnt of the genes involved in DNA metabolism and repair and their role in a variety of pathologies, such as defects in BRCA1 that cause increased risk for breast cancer (Nathanson et al. 2001; Thompson \& Schild, 2002), much less is known of the impact of cofactor and/or micronutrient deficiency on DNA repair. Put simply, a deficiency in a micronutrient required as a cofactor or as an integral part of the structure of a DNA repair gene (for example, $\mathrm{Zn}$ as a component of the DNA repair glycosylase OGG1 involved in removal of oxidised guanine or Mg as a cofactor for several DNA polymerases) could mimic the effect of a genetic polymorphism that reduces the activity of that enzyme (Ames, 2001, 2003). Therefore nutrition has a critical role in DNA metabolism and repair and this awareness is leading to the development of the new field of nutritional genomics of genome stability. The purpose of the present paper is to:

(a) briefly review the link between genome instability and adverse health outcomes during the various stages of life;

\footnotetext{
Abbreviations: BFB, breakage-fusion-bridge; BN, binucleated; CBMN, cytokinesis-block micronucleus; MN, micronucleus; MNi, micronuclei; MTHFR, methylene tetrahydrofolate reductase; NPB, nucleoplasmic bridge; RDA, recommended dietary allowances.

Corresponding author: Dr Michael Fenech, fax +61 88303 8880, email Michael.Fenech@csiro.au
} 
(b) examine the evidence for genome instability as a marker of nutritional deficiency;

(c) explain the application of the micronucleus (MN) assay as an efficient biomarker for diagnosing genome instability and nutritional deficiency;

(d) introduce the concept of recommended dietary allowances (RDA) for genome stability and how this could be achieved;

(e) provide some insight into the importance of the emerging field of nutritional genomics for genome stability;

(f) describe, briefly, the framework for a disease-prevention strategy based on the diagnosis and nutritional treatment of genome instability.

\section{The evidence linking genome damage with adverse health outcomes during the various stages of life}

Genome damage impacts on all stages of life. There is good evidence to show that infertile couples exhibit a higher rate of genome damage than fertile couples (Trkova et al. 2000) when their chromosomal stability is measured in lymphocytes using the MN assay (Fenech, 2000). The infertility may be due to a reduced production of germ cells because genome damage effectively causes programmed cell death or apoptosis, which is one of the mechanisms by which grossly mutated cells are eliminated (Narula et al. 2002; Ng et al. 2002; Hsia et al. 2003). When the latter mechanism fails, reproductive cells with genomic abnormalities may survive leading to serious developmental defects (Liu et al. 2002; Vinson \& Hales, 2002). There is ample evidence to show that most genotoxic carcinogens are also teratogens (O’Brien et al. 1996; Yu et al. 1999). Similarly, micronutrient deficiencies that cause genome damage may themselves cause developmental defects in the fetus or increased risk of cancer in the child. Specific examples include: (a) increased oxidation of sperm DNA in individuals with inadequate vitamin C intake (Fraga et al. 1991); (b) neural tube defects in folate-deficient fetuses at deficiency levels that coincide with increased genome damage rate (Fenech, 2001; Green, 2002); (c) the observation that Zn deficiency, which induces oxidative damage to DNA and impairs DNA repair, is itself teratogenic (Dreosti, 2001; Ho \& Ames, 2003).

There is emerging evidence that genome damage or inappropriate gene expression experienced in the fetal stage of development may lead to abnormalities such as neural tube defects or a higher risk of childhood cancers such as leukaemia. The risk for both these conditions is increased when folate is limiting (Thompson et al. 2001; Brody et al. 2002). The risk of mutations is relatively high during early development and childhood because a much larger proportion of cells are in the DNA synthesis phase, which is more prone to insult by genotoxins or genome damage by micronutrient insufficiency. That an elevated rate of chromosomal damage is a cause of cancer has been proven by ongoing prospective cohort studies in Italy and the Scandinavian countries, which demonstrated a 2- to 3-fold increased risk of cancer in those whose chromosomal damage rate in lymphocytes was shown to be in the highest tertile when measured 10-20 years before cancer incidence was measured (Bonassi et al. 2000).
Chromosomal damage is also associated with accelerated ageing and neurodegenerative diseases. Several studies have shown that chromosomal abnormalities, including $\mathrm{MN}$ frequency, increase progressively with age in somatic cells (Bonassi et al. 2001). Accelerated ageing and cancerprone syndromes, such as progeria, Bloom's syndrome, Fanconi's anaemia and Werner's syndrome, exhibit increased chromosomal instability and/or accelerated telomere shortening due to defects in a variety of genes essential for DNA repair and telomere maintenance such as ATM, poly(ADP-ribose) polymerase, BRCA1, BRCA2 and DNA helicases (Lansdorp, 2000; Joenje \& Patel, 2001, Shen \& Loeb, 2001; Thompson \& Schild, 2002). Equally interesting is the observation that neurodegenerative diseases such as Alzheimer's disease and Parkinson's disease exhibit much higher rates of MN frequency in peripheral blood lymphocytes (Migliore et al. 1999, 2001). In the case of Alzheimer's disease, there is also evidence that the frequency of cells exhibiting trisomy 21 is elevated, which leads to the hypothesis that these individuals may be mosaics for the Down's syndrome phenotype, which is associated with accelerated ageing and increased risk of neurodegenerative disease (Migliore et al. 1999).

Increased chromosomal DNA damage may be partly due to inefficient or incorrect DNA repair, which increases the sensitivity of an individual's cells to normal genotoxic stresses. A typical example is cells from individuals with truncation mutations in the BRCA1 and BRCA2 genes, which result in a highly penetrant condition for increased breast cancer risk (Venkitaraman, 2002). These genes are required for the error-free homologous recombinational repair of double-stranded breaks in DNA (Thompson \& Schild, 2002). In the absence of normal function of these genes, non-homologous end-joining repair occurs, which leads to exchanges between chromosomes and the formation of abnormal chromosomal structures such as dicentric chromosomes and chromosome fragments (Venkitaraman, 2002). These abnormal chromosomes lead to a chromosomal instability phenotype because of the difficulty in segregating dicentric chromosomes equally between cells leading to the formation of the so-called breakage-fusion-bridge (BFB) cycles, which in turn lead to gene amplification and altered gene dosage (for a detailed account of these mechanisms, see Fenech, 2002). This genome instability phenotype, involving BFB cycles, is typical of most cancer cells (Saunders et al. 2000; Gisselson et al. 2001). The DNA repair deficiency phenotype is readily diagnosed using a radiation challenge to primary cells and scoring chromosomal damage events using a variety of classical cytogenetic methods that can detect anaphase or nucleoplasmic bridges (NPB) formation (Fenech, 2002). This phenotype of DNA misrepair is associated with elevated risk of a variety of cancers including head and neck cancers, colorectal cancer, breast cancer and myelodysplastic syndrome (Scott et al. 1998; Rothfus et al. 2000; Baria et al. 2002; Kuramoto et al. 2002).

Apart from faulty DNA repair, other defects in mechanisms involved in chromosome segregation may lead to abnormal chromosome number or aneuploidy, an event that is increasingly being considered as a potential cancer-initiating event and a definite cause of developmental abnor- 
malities. Important mechanisms include defects in assembly of the spindle, inadequate mitotic cycle checkpoints and abnormal replication of the centrosome, which coordinates the assembly of the spindle (Fenech, 2002). Duesberg and colleagues (Duesberg et al. 2000; Li et al. 2000) have suggested that induction of aneuploidy (abnormal number of chromosomes) either by a chemical agent or by other means such as a genetic abnormality in the mechanism of chromosome segregation or a defect in microtubule polymerization due to a deficiency in an essential cofactor such as Mg (Hartwig, 2001) may cause altered dosages of oncogenes and tumour suppressor genes. Duesberg's aneuploidy hypothesis of carcinogenesis also predicts that aneuploidy involving chromosomes containing genes that control the mitotic process leads to asymmetric segregation of chromosomes, initiating an autocatalytic karyotypic evolution generating pre-neoplastic and ultimately cancer cells. This hypothesis would explain why cancer cells are often aneuploid; however it would not necessarily explain the high frequency of chromosomal fragment translocations and gene amplification often seen in cancer, which may be better explained by the BFB cycle mechanism of hypermutation (explained later; p. 116). However, a potential unifying mechanism can be discerned from the recent observations that proteins involved in homologous recombination repair of DNA breaks such as XRCC2 and XRCC3 are found to be located at the centriole and that loss of function mutations in these genes leads to abnormal centrosome replication, multipolar mitoses and therefore aneuploidy (Griffin et al. 2000; Griffin, 2002). In addition, unequal segregation of dicentric chromosomes caused by asymmetric exchanges following misrepair of double-strand breaks may also lead to aneuploidy. The role of centrosome abnormalities in cancer first proposed by Boveri (1929) is now increasingly being confirmed for a variety of cancers such as prostate cancer in which the level of these abnormalities has been shown to accumulate with progression to a more malignant state (Pihan et al. 1998, 2001). Which micronutrients are required for proper centrosome replication and function remains unknown and uninvestigated.

\section{The concept of genome damage as a marker of nutritional deficiency}

There is overwhelming evidence that a large number of vitamins and minerals are required as cofactors for enzymes or as part of the structure of proteins (metalloenzymes) involved in DNA synthesis and repair, prevention of oxidative damage to DNA as well as maintenance methylation of DNA. The role of micronutrients in the maintenance of genome stability has recently been extensively reviewed (Fenech \& Ferguson, 2001; Ames \& Wakimoto, 2002). Examples of micronutrients involved in various genome stability processes are given in Table 1 . The main point is that micronutrient deficiency can cause genome damage and as explained later (pp. 111-116) the increments in genome damage caused by micronutrient deficiency are of the same order of magnitude, if not greater, than the genome damage levels caused by exposure to significant doses of environmental genotoxins such as chemical carcinogens, u.v. radiation and ionising radiation. An example from our laboratory is the observation that the chromosomal damage rate caused by reducing folate concentration from 120 to $12 \mathrm{nmol} / \mathrm{l}$ is equivalent to that induced by an acute exposure to 0.2 Gy of low linear energy transfer ionising radiation (for example, X-rays), a dose that is approximately ten times greater than the annual allowed safety limit of exposure for the general population (Cruz Suarez et al. 2001) (Fig. 1). These results imply that genome damage biomarkers are not only biodosimeters of exposure to manmade or natural genotoxins, but are also biodosimeters of deficiency in micronutrients required: (a) for the prevention of oxidation to DNA (i.e. antioxidants); (b) for the prevention of uracil incorporation into DNA (i.e. folate); (c) for the maintenance methylation of $\mathrm{CpG}$ in DNA (methionine, choline, folate, $\mathrm{B}_{12}$ ); (d) as cofactors or as components of DNA repair enzymes (for example, $\mathrm{Zn}, \mathrm{Mg}$ ); (e) for maintenance of telomere length (for example, niacin, folate). The sensitivity of DNA damage to micronutrient deficiency is underscored by the fact that the eight known human DNA repair glycosylases are dedicated to the removal of the type of DNA base damage that is produced when either antioxidant micronutrients (such as $\mathrm{Zn}$, vitamins $\mathrm{C}$ and $\mathrm{E}$ ) or folate, methionine and vitamin $\mathrm{B}_{12}$ are deficient (Table 2).

\section{The micronucleus assay as a biomarker for diagnosing genome damage and nutritional deficiency}

Micronuclei $(\mathrm{MNi})$ originate from chromosome fragments or whole chromosomes that lag behind at anaphase during nuclear division (Fig. 2) (Fenech et al. 1999; Fenech, 2002). The MN index in rodent and/or human cells has become one of the standard cytogenetic tests for genetic toxicology testing of chemicals and radiation in vivo or ex vivo. The MN assay can be practically measured

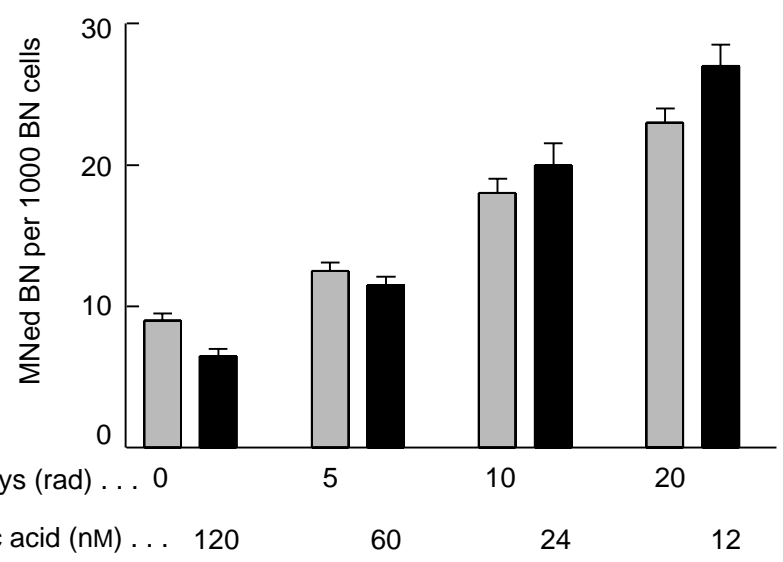

Fig. 1. A comparison of the dose-response effect on micronucleus induction in cytokinesis-blocked cultured lymphocytes caused by acute exposure to X-rays $(\square ; n 6)$ up to a maximum dose of $20 \mathrm{rad}$ (0.2Gy), equivalent to 100 times the annual exposure safety limit for the general public (Cruz Suarez et al. 2001), and folic acid deficiency within the 'normal' physiological range of $12-120 \mathrm{~nm}$ concentration $(\boldsymbol{\square} ; n$ 20). Results are mean values, with standard errors of the mean represented by vertical bars. MNed, micronucleated; BN, binucleated (data from Fenech \& Morley, 1986; Crott et al. 2001a,b). 
Table 1. Examples of the role and the effect of deficiency of specific micronutrients on genomic stability*

\begin{tabular}{|c|c|c|}
\hline Micronutrient/s & Role in genomic stability & Consequence of deficiency \\
\hline Vitamin C, Vitamin E & $\begin{array}{l}\text { Prevention of oxidation to DNA and lipid } \\
\text { oxidationt }\end{array}$ & $\begin{array}{l}\text { Increased base-line level of DNA strand breaks, } \\
\text { chromosome breaks and oxidative DNA lesions } \\
\text { and lipid peroxide adducts on DNA† }\end{array}$ \\
\hline $\begin{array}{l}\text { Folate and Vitamins } \\
\mathrm{B}_{2}, \mathrm{~B}_{6} \text { and } \mathrm{B}_{12}\end{array}$ & $\begin{array}{l}\text { Maintenance methylation of DNA; synthesis of } \\
\text { dTTP from dUMP and efficient recycling of } \\
\text { folateł }\end{array}$ & $\begin{array}{l}\text { Uracil misincorporation in DNA, increased } \\
\text { chromosome breaks and DNA hypomethylation } \neq\end{array}$ \\
\hline Niacin & $\begin{array}{l}\text { Required as substrate for PARP which is } \\
\text { involved in cleavage and rejoining of DNA } \\
\text { and telomere length maintenance§ }\end{array}$ & $\begin{array}{l}\text { Increased level of unrepaired nicks in DNA, } \\
\text { increased chromosome breaks and } \\
\text { rearrangements, and sensitivity to mutagens§ }\end{array}$ \\
\hline $\mathrm{Zn}$ & $\begin{array}{l}\text { Required as a cofactor for } \mathrm{Cu} / \mathrm{Zn} \text { superoxide } \\
\text { dismutase, endonuclease IV, function of p53, } \\
\text { Fapy glycosylase and in } \mathrm{Zn} \text { finger proteins } \\
\text { such as PARP } \|\end{array}$ & $\begin{array}{l}\text { Increased DNA oxidation, DNA breaks and } \\
\text { elevated chromosome damage rate\| }\end{array}$ \\
\hline $\mathrm{Fe}$ & $\begin{array}{l}\text { Required as component of ribonucleotide } \\
\text { reductase and mitochondrial cytochromes }\end{array}$ & $\begin{array}{l}\text { Reduced DNA repair capacity and increased } \\
\text { propensity for oxidative damage to } \\
\text { mitochondrial DNA } 9\end{array}$ \\
\hline $\mathrm{Mg}$ & $\begin{array}{l}\text { Required as cofactor for a variety of DNA } \\
\text { polymerases, in nucleotide excision repair, } \\
\text { base excision repair and mismatch repair. } \\
\text { Essential for microtubule polymerisation } \\
\text { and chromosome segregation }{ }^{\star *}\end{array}$ & $\begin{array}{l}\text { Reduced fidelity of DNA replication. Reduced } \\
\text { DNA repair capacity. Chromosome } \\
\text { segregation errors }{ }^{\star \star}\end{array}$ \\
\hline $\mathrm{Mn}$ & $\begin{array}{l}\text { Required as a component of mitochondrial } \\
\text { Mn superoxide dismutase } \dagger\end{array}$ & $\begin{array}{l}\text { Increased susceptibility to superoxide damage to } \\
\text { mitochondrial DNA and reduced resistance to } \\
\text { radiation-induced damage to nuclear DNA†† }\end{array}$ \\
\hline
\end{tabular}

PARP, poly(ADP-ribose) polymerase; dTTP, deoxythymidine triphosphate; dUMP, deoxyuridine monophosphate.

${ }^{*}$ For information on other micronutrients (for example, carotenoids, vitamin D, polyphenols, Se and Cu), refer to other papers in Fenech \& Ferguson (2001). †Halliwell (2001); Claycombe \& Meydani (2001).

¥Fenech (2001).

§Hageman \& Stierum (2001).

||Dreosti (2001); Ho \& Ames (2003).

TWalter et al. (2002).

${ }^{* *}$ Hartwig (2001).

†† Keen \& Zidenberg-Cherr (1996); Ambrosone et al. (1999).

Table 2. DNA glycosylases in human cell nuclei (from Lindahl \& Wood, 1999)

\begin{tabular}{ll}
\hline Enzyme & Altered base removed \\
\hline UNG & U and 5-hydroxyuracil \\
TDG & U or T opposite G, ethenocytosine \\
hsMUG1 & U (preferentially from SS DNA) \\
MBD4 & U or T opposite G at CpG sequences \\
hOGG1 & 8-OxoG opposite C \\
MYH & A opposite 8-oxoG \\
hNTH1 & Thymidine glycol, cytosine glycol, dihydrouracil, \\
formamidopyridine
\end{tabular}

in erythrocytes, buccal cells or lymphocytes to obtain a measure of genome damage induced in vivo. MNi in erythrocytes originate from genome damage events in their precursors (normoblasts) in the bone marrow (for more detailed explanation, see Fig. 3). MNi in buccal cells originate from genome damage events in the basal layer of the oral mucosa (for more detailed explanation, see Fig. 4). In the case of lymphocytes it is possible to score $\mathrm{MNi}$ expressed in vivo directly (Fenech et al. 1999); however, a more comprehensive approach is to culture the lymphocytes because this allows a measure of genome damage that is accumulated while lymphocytes circulate around the body in the quiescent phase (Fig. 5). Lymphocytes have a half-life of 3-6 months and travel throughout the body, integrating genotoxic events across body tissues. In comparison, buccal cells and erythrocytes turn over every 21 and $120 \mathrm{~d}$, respectively.

The earliest studies on the relationship between MN induction and micronutrient deficiency were performed using the erythrocyte $\mathrm{MN}$ assay. In fact $\mathrm{MNi}$ were first noted by haematologists and they are still referred to as Howell-Jolly bodies in recognition of the scientists who first described the relationship between megaloblastic anaemia and the prevalence of $\mathrm{MNi}$ in erythrocytes or in their immature stage, i.e. reticulocytes (Lessin \& Bessis, 1972). This was the first evidence that folate and/or vitamin $\mathrm{B}_{12}$ deficiency induces chromosomal instability. It eventually became evident that the sensitivity to dietary deficiency and inter-individual variability of the erythrocyte MN assay could be improved if the subject being investigated happened to be splenectomised because, in man, the spleen removes micronucleated erythrocytes from circulation (Everson et al. 1988). Using splenectomised human subjects, it was shown that supplementation with folic acid and the vitamins A, C or E was associated with a lower MN frequency and that drinking more than five cups of coffee or tea per $\mathrm{d}$ and consumption of $\mathrm{Ca}$ supplements were associ- 


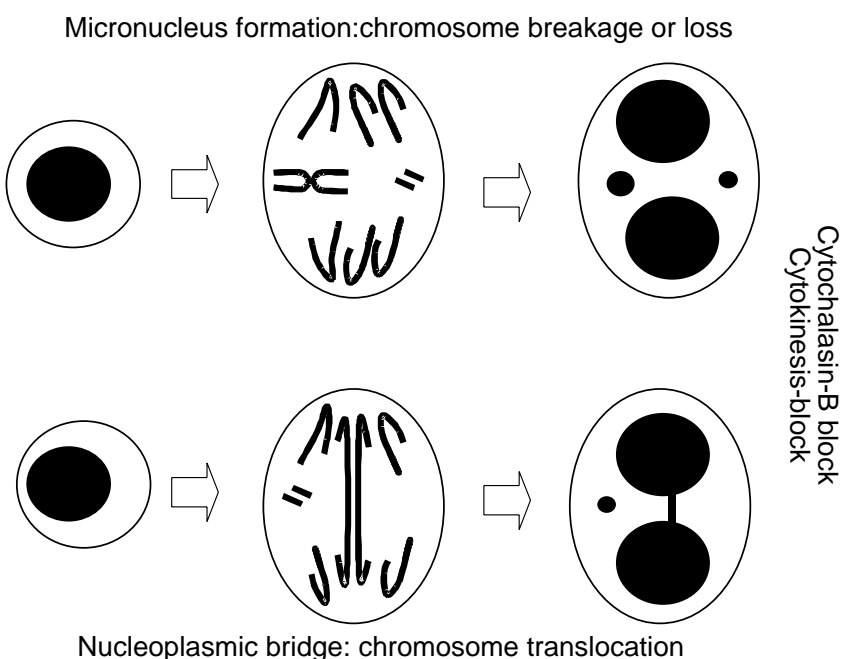

Fig. 2. Expression of micronuclei (MNi) and nucleoplasmic bridge (NPB) during nuclear division. MNi originate from either (a) lagging whole chromosomes (top panel) that are unable to engage with the mitotic spindle due to a defect in the spindle, or a defect in the centromere-kinetochore complex required to engage with the spindle or (b) an acentric chromosome fragment originating from a chromosome break (top and bottom panels) which lags behind at anaphase because it lacks a centromere-kinetochore complex. Misrepair of two chromosome breaks may lead to an asymmetrical chromosome rearrangement producing a dicentric (i.e. two centromeres) chromosome and an acentric fragment (bottom panel); frequently the centromeres of the dicentric chromosome are pulled to opposite poles of the cell at anaphase resulting in the formation of an NPB between the daughter nuclei. NPB are frequently accompanied by a micronucleus originating from the associated acentric chromosome fragment. Because MNi and NPB are only expressed in cells that have completed nuclear division it is necessary to score these genome instability biomarkers specifically in once-divided cells. This is readily accomplished by blocking cytokinesis using cytochalasin-B (for a more detailed explanation, see Fenech, 2002; Thomas et al. 2003).

ated with an increase in MN frequency (Everson et al.1988; Smith et al. 1990). Using the same model in mice MacGregor and colleagues showed that MN induction by folate deficiency was aggravated by increased caffeine intake and that $\mathrm{Mg}$ deficiency doubled the $\mathrm{MN}$ frequency in fetal and maternal blood (MacGregor, 1990; MacGregor et al. 1990). Recently, a flow cytometric method for scoring $\mathrm{MNi}$ in nascent (immature) erythrocytes has been described, making this method practical for dietary studies in which small alterations in genome damage rate may be expected (Abramsson-Zetterberg et al. 2000). In the latter study it was observed that MN frequency in erythrocytes was significantly and negatively correlated with vitamin $\mathrm{B}_{12}$ status.

Although the buccal cell MN assay has been successfully applied to demonstrate elevated spontaneous genome damage rate in individuals with inherited genome instability syndromes such as Bloom's syndrome (Rosin \& German, 1985; Honma et al. 2002) and in those exposed to chemical genotoxins (Kassie et al. 2001) or ionising radiation (Moore et al. 1996), much less is known about the impact of dietary deficiency on this index with only three

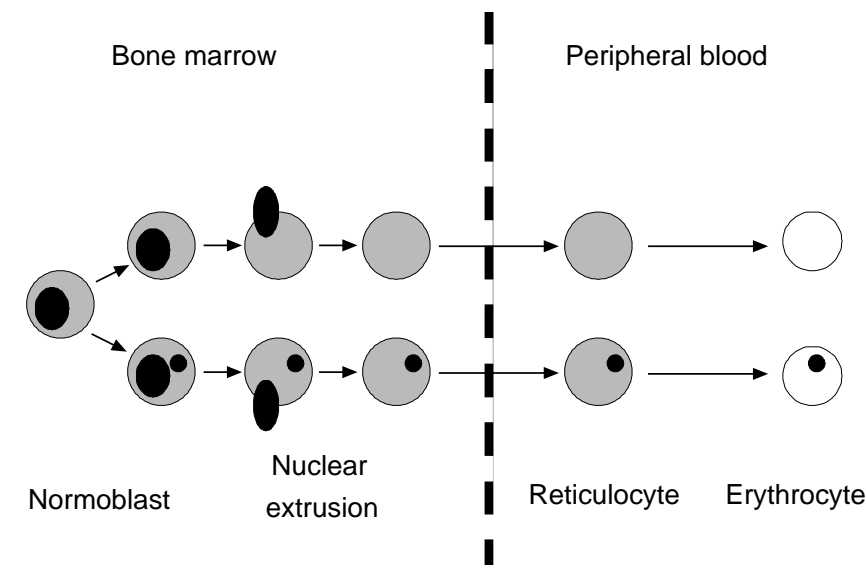

Fig. 3. Micronucleus formation in erythrocytes. Genome instability events in the normoblasts in the bone marrow lead to chromosome breakage or loss and micronucleus formation in the precursor cells of erythrocytes, the reticulocytes. During the maturation process to the reticulocyte stage, nuclei are excluded but micronuclei remain in the reticulocyte. The reticulocyte (with or without a micronucleus) eventually enters the peripheral blood and becomes a fully mature erythrocyte (with or without a micronucleus). Erythrocytes containing a micronucleus are eventually eliminated by the spleen; therefore the assay is best performed in individuals that have been splenectomized or by using a method that allows isolation of nascent reticulocytes identified by the presence of the transferrin receptor. The reticulocyte is distinguishable from the erythrocyte by its larger size and much higher RNA content. Micronucleus frequencies in reticulocytes and erythrocytes are usually recorded separately (for a more detailed explanation, see MacGregor et al. 1990; Abramsson-Zetterberg et al. 2000).

studies reporting on the effect of diet. The first report of a dietary intervention using buccal mucosal cells was that of Stich et al. (1984) in which a $\beta$-carotene and retinol supplement given to betel-nut chewers was shown to decrease MN frequency by $66 \%$, while the unsupplemented group showed no change. The second by Piyathilake et al. (1995), a cross-sectional study on smokers and non-smokers, showed a three-fold increment in MN frequency in smokers who also had lower buccal mucosal folate and $\mathrm{B}_{12}$ when compared with non-smokers. The third by Titenko-Holland et al. (1998), a depletion-repletion study of nine postmenopausal women, showed a reduction in MN frequency in the buccal exfoliated cells after dietary supplementation with $516 \mu \mathrm{g}$ folate/d. None of these studies made allowance for the possible effects of supplements on cell division kinetics, which may influence $\mathrm{MN}$ expression. For an extensive review of the application of the MN assay in buccal cells as well as other exfoliated cells (for example, cervical epithelium), refer to Majer et al. (2001).

The cytokinesis-block micronucleus (CBMN) assay is the preferred method for measuring $\mathrm{MNi}$ in cultured human lymphocytes because scoring is specifically restricted to once-divided cells. These cells are recognised by their binucleated $(\mathrm{BN})$ appearance after inhibition of cytokinesis by cytochalasin-B (Fenech \& Morley, 1986; Fenech, 2002). Restricting scoring of $\mathrm{MNi}$ in $\mathrm{BN}$ cells prevents confounding effects caused by altered cell division kinetics, which is a major variable in this ex vivo assay. Over the past 17 


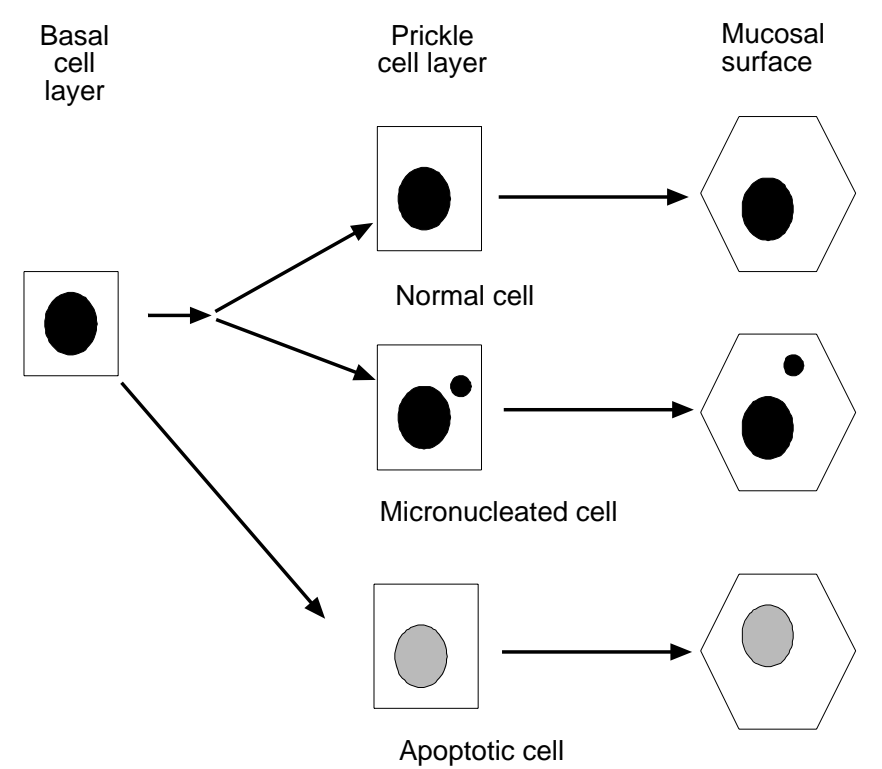

Fig. 4. Micronucleus (MN) formation in buccal cell mucosa. Genome instability in the basal cells leads to chromosome breakage or loss and MN formation. Some cells with genome damage may be eliminated via the apoptotic process. The daughter cells from the basal layer differentiate into 'prickle cells' which are eventually differentiated into the flattened and keratinised surface mucosal cells. Each of these cell types may contain an MN. The frequency of micronuclei observed may depend on the proportion of the various cell types scored (for a more detailed account of mucosal cell biology and micronucleus expression, see Rosin \& German, 1985; Wertz \& Squier, 1991; Titenko-Holland et al. 1998).

years the CBMN assay has evolved into a comprehensive method for measuring chromosome breakage, chromosome loss, non-disjunction, gene amplification, necrosis, apoptosis and cytostasis (Fig. 5).

The results of cross-sectional studies of vegetarians and non-vegetarians (Fenech \& Rinaldi, 1995), older men (Fenech et al. 1997b) and young adults (Fenech et al. 1998; Odagiri \& Uchida, 1998) indicated that MN frequency in lymphocytes was negatively correlated with plasma folate and vitamin $\mathrm{B}_{12}$, positively correlated with homocysteine and vitamin $\mathrm{C}$ and unrelated to vitamin $\mathrm{E}$ status. Placebocontrolled dietary interventions have shown that supplementation with $700 \mu \mathrm{g}$ folic acid and $2.5 \mu \mathrm{g}$ vitamin $\mathrm{B}_{12}$ (Fenech et al. 1998) reduced MN frequency in lymphocytes by $25 \%$, which is in accordance with the predictions from the cross-sectional data (Fenech \& Rinaldi, 1995). Supplementation with vitamin E (Fenech et al. 1997a) or vitamin C (Crott \& Fenech, 1999) did not decrease MN frequency in lymphocytes. A depletion-repletion study in nine post-menopausal women showed a decrease in lymphocyte MN frequency following repletion with $516 \mu \mathrm{g}$ folic acid/d (Titenko-Holland et al. 1998). Daily intake over a 4-month period of a multivitamin, containing $15 \mathrm{mg} \beta$-carotene, 75 $\mathrm{mg}$ rutin, $3 \mathrm{mg}$ retinyl acetate, $30 \mathrm{mg} \alpha$-tocopherol, $150 \mathrm{mg}$ ascorbic acid and $0.2 \mathrm{mg}$ folic acid, resulted in a significant reduction of baseline MN frequency in lymphocytes from older subjects (56-80 years) and increased the resistance of lymphocytes to radiation-induced MNi in both younger and older adults (Gaziev et al. 1996).
Cytokinesis-block micronucleus assay

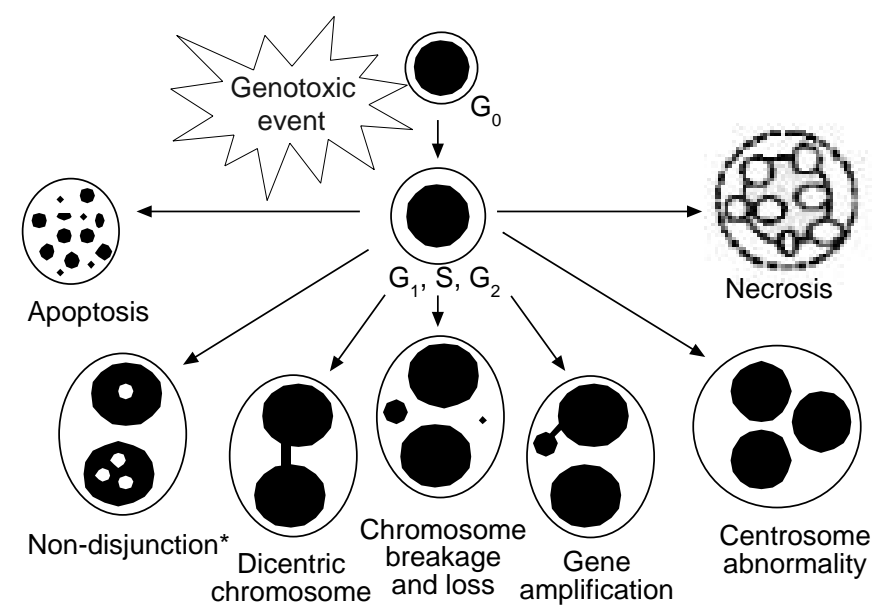

Fig. 5. The various possible fates of cultured cytokinesis-blocked lymphocytes following exposure to cytotoxic and genotoxic agents or micronutrient deficiency. Using these biomarkers within the cytokinesis-blocked micronucleus assay it is possible to measure the frequency of chromosome breakage (micronucleus), chromosome loss (micronucleus), chromosome rearrangement, for example, dicentric chromosomes (nucleoplasmic bridge), gene amplification (nuclear buds), necrosis and apoptosis. In addition, cytostatic effects are readily estimated from the ratio of mono-, biand multinucleated cells. Chromosome loss can be distinguished from chromosome breakage using pancentromeric probes or antikinetochore antibodies. In addition, non-disjunction (malsegregation of chromosomes) can also be measured in binuclear cells using chromosome-specific centromeric probes. In the example shown, non-disjunction results in one nucleus containing only one chromosome (i.e. one less than normal diploid state; monosomy) and the other nucleus containing three homologous chromosomes (i.e. one more than the normal diploid state; trisomy). Both monosomy and trisomy of specific chromosomes are associated with developmental defects and cancer risk (Fenech, 2002).

More recently it has been proposed that NPB between nuclei in BN cells should also be scored in the CBMN assay because they provide a measure of chromosome rearrangement, which is otherwise not measured in this assay if only MNi are scored (Thomas et al. 2003). The NPB are assumed to occur when the centromeres of dicentric (abnormal, rearranged) chromosomes are pulled to opposite poles of the cell at anaphase. It is rarely possible to observe dicentric anaphase bridges before the nuclear membrane is formed, because cells proceed through anaphase and telophase rapidly, completing cytokinesis and ultimately breakage of the NPB when the daughter cells separate. However in the CBMN assay, BN cells with NPB are allowed to accumulate because cytokinesis is inhibited and the nuclear membrane is eventually formed around the chromosomes allowing an NPB to be observed.

Over the past decade another unique mechanism of MN formation, known as nuclear budding, has emerged. This process has been observed in cultures grown under strong selective conditions (Toledo et al. 1992; Ma et al. 1993; Shimura et al. 1999) that induce gene amplification. Shimizu et al. $(1998,2000)$ showed that amplified DNA is selectively localised to specific sites at the periphery of the 
nucleus and eliminated via nuclear budding to form $\mathrm{MNi}$ during the $\mathrm{S}$ phase of mitosis. Furthermore, DNA synthesis inhibitors such as hydroxyurea were shown to increase the rate of elimination of amplified DNA via this process. Amplified DNA may be eliminated through recombination between homologous regions within amplified sequences forming minicircles of acentric and atelomeric DNA (double minutes), which localise to distinct regions within the nucleus or through the excision of amplified sequences after segregation to distinct regions of the nucleus. This suggests that the nucleus may have a capacity to sense excess DNA that does not fit well within the nuclear matrix indicating a higher-order DNA repair or nuclear housekeeping process. Shimizu et al. (1998, 2000) have suggested that the nucleus eliminates excess amplified DNA by an active process that concentrates the amplified DNA to a peripheral point in the nucleus, following which this surplus DNA is budded out to form a MN and eventually excluded from the cell altogether by extrusion of the MN from the cytoplasm leading to the formation of a "minicell'.

In a recent study on folic acid deficiency in long-term primary human lymphocyte cultures the inter-relationship between MNi, NPB and nuclear buds was carefully quantified in an attempt to validate the use of these biomarkers and to determine more comprehensively the impact of folic acid deficiency on various aspects of genomic stability (Crott et al. 2001a,b). Briefly, lymphocytes from twenty (eight male, twelve female) asymptomatic volunteers (34-65 years) were cultured in duplicate in RPMI-1640 medium containing $5 \%$ dialysed fetal calf serum, interleukin-2 $(10 \mathrm{U} / \mathrm{ml})$ and either $12,24,60$ or $120 \mathrm{nM}$-folic acid for $9 \mathrm{~d}$. The medium was refreshed at days 3 and 6, cytokinesis was inhibited on day 8 and cells were transferred to microscope slides $24 \mathrm{~h}$ later. The pooled data from this study verified that folic acid concentration correlated significantly $(P<0.0001)$ and negatively $(r-0.63$ to -0.74$)$ with uracil in DNA and micronucleated cells, which were minimised at 60-120 nM-folic acid, the latter being greater than the concentration of folate normally observed in plasma (10-30 nM) (Fig. 6). However, even more interestingly, it was observed that the frequency of NPB and nuclear buds correlated significantly and negatively with folic acid dose, suggesting that chromosome rearrangement and gene amplification are induced by folic acid deficiency. The strong cross-correlation between MN, NPB and nuclear bud frequency $(r 0.75$ to $0.77, P<0.001)$ suggests a common mechanism initiated by folic acid deficiency-induced DNA breaks, although coincidence of effects with other DNA damage events (for example, folic acid deficiencyinduced $\mathrm{CpG}$ hypomethylation) cannot be excluded.

Because folic acid deficiency is known to cause gene amplification and chromosome damage such as doublestranded breaks (Blount \& Ames, 1995; Blount et al. 1997; Melnyk et al. 1999; Fenech, 2001), it is probable that these
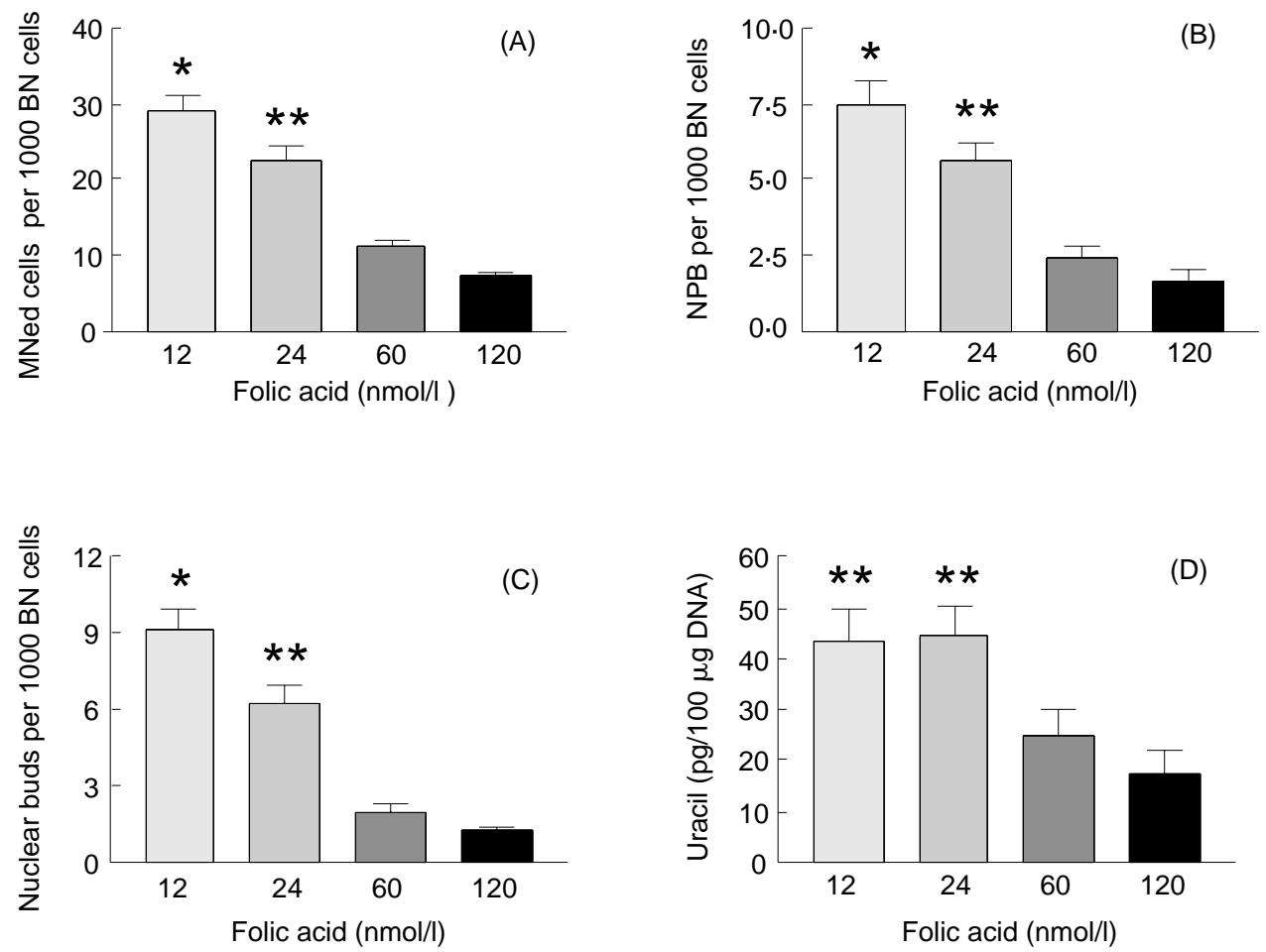

Fig. 6. The effect of medium folic acid concentration on the induction of (A), micronucleated binucleated (MNed BN) cells; (B), nucleoplasmic bridges (NPB); (C), nuclear buds; (D), uracil in primary human lymphocytes in vitro. Values are means, with standard errors of the mean represented by vertical bars for twenty human subjects. Results from ANOVA were $P<0.0001$ for (A)-(C) and $P<0.001$ for (D). * Mean value was significantly different from those for 24,60 and $120 \mathrm{nM}(P<0.01)$; ${ }^{* *}$ mean value was significantly different from those for 60 and $120 \mathrm{~nm}$ $(P<0.01)$ (Tukey's post-hoc test). Data from Crott et al. $(2001 a, b)$. 
events contribute to the formation of $\mathrm{MNi}, \mathrm{NPB}$ and nuclear buds in this system. Gene amplification is thought to be a key event in cellular resistance to drugs like methotrexate (Biedler \& Spengler, 1976) and in tumour progression (Brison, 1993). Several plausible models of gene amplification have been proposed (Windle \& Wahl, 1992; Stark, 1993); however, the presence of NPB in the cytokinesis-blocked cells provides support for the BFB cycle model described in the seminal work of McClintock (1942) in maize. According to this theory, sister chromatids, which have both undergone double-stranded breakage, fuse at a distal position (possibly telomeric) forming a dicentric chromosome that has two copies of homologous genes positioned between the two centromeres. During anaphase these dicentric chromosomes are drawn towards both poles and form (nucleoplasmic) bridges. During cytokinesis these dicentric chromosomes, which span both daughter nuclei, are thought to break unevenly and may form a chromosome with two copies of one or more genes and a chromosome (fragment) with no copies of these genes. The chromatids with multiple copy number of these genes may fuse again during interphase forming a dicentric chromosome (doubling again the gene copy number within the chromosome), which is then replicated during the next nuclear division leading to the next BFB cycle and further gene amplification.

Folic acid deficiency-induced fragile site expression and DNA hypomethylation may have also contributed to the promotion of gene amplification and resulted in elimination of this DNA by nuclear budding in our system. For example, amplification of the multi-drug resistance 1 gene in Chinese hamster cells occurs through the induction of fragile sites that determine the initiation and size of amplicons (Coquelle et al. 1997), and the induction of hypomethylation by 5 -aza- 2 ' deoxycytidine has been reported to enhance $\mathrm{N}$-(phosphonylacetyl)-L-aspartate-induced amplification of the CAD gene in Syrian hamster kidney cells (Perry et al. 1992).

In summary, the genomic instability phenotype can be readily recognised simply by examining cells for abnormal nuclear morphology indicative of BFB cycles, i.e. $\mathrm{MNi}, \mathrm{NPB}$ and nuclear blebs. In addition, genomic instability can also be manifested by a high rate of aneuploidy and multipolar mitoses, which are detectable by fluorescence in situ hybridisation with chromosome-specific centromere probes or cytologically, respectively. One of the better methods for measuring and observing BFB cycles and non-disjunction and chromosome loss is the CBMN assay. The results with folic acid show quite clearly that micronutrient deficiencies can on their own cause the type of genomic instability observed in cancer. In fact these observations: (a) have provided further impetus for the concept that the RDA should be based on the prevention of genomic instability; (b) highlight the potential of micronutrient concentration as an important modifier not only of spontaneous chromosome abnormality but also chemically induced genome damage. These points have important implications in the relative risk assessment of chemical and radiation exposure depending on micronutrient status.

\section{The concept of recommended dietary allowances for genome stability}

Current RDA for vitamins and minerals are based largely on the prevention of diseases of deficiency such as scurvy in the case of vitamin $\mathrm{C}$, anaemia in the case of folic acid and pellagra in the case of niacin. However, these diseases of deficiency are rare in the developed world but degenerative disease and developmental disease are very important. Recently the dietary allowance for folic acid for the prevention of neural tube defects has been revised to more than double the original RDA (Centers for Disease Control, 1992). There is a strong international awareness that it is also necessary to redefine RDA for the prevention of degenerative disease (such as cancer, cardiovascular disease and Alzheimer's disease) and compression of the morbidity phase during old age. Because diseases of development, degenerative disease and ageing itself are partly caused by damage to DNA (Holliday, 1995; Ames, 1998, 1999) it seems logical that our attention would be better focused on defining optimal requirements of key minerals and vitamins for preventing damage to both nuclear and mitochondrial DNA. To date our knowledge on optimal micronutrient levels for genomic stability is scanty and disorganised.

Both in vitro and in vivo studies with human cells clearly show that folate deficiency, vitamin $B_{12}$ deficiency and elevated plasma homocysteine are associated with expression of chromosomal fragile sites, chromosome breaks, excessive uracil in DNA, MN formation and DNA hypomethylation (Jacky et al. 1983; Everson et al. 1988; Cravo et al. 1994; Blount \& Ames, 1995; Blount et al. 1997; Duthie \& Hawdon, 1998; Fenech et al. 1998; Jacob et al. 1998; Titenko-Holland et al. 1998; Crott et al. 2001a,b). In vitro experiments indicate that DNA breaks in human cells are minimised when folic acid concentration in culture medium is greater than $180 \mathrm{nmol} / \mathrm{l}(80 \mathrm{ng} / \mathrm{ml})$ (Jacky et al. 1983; Duthie \& Hawdon, 1998). Recently it has been shown that uracil incorporation in human lymphocytes cultured for $8 \mathrm{~d}$ is minimised at a folic acid concentration of $120 \mathrm{nmol} / \mathrm{l}$ (Crott et al. 2001a,b). Intervention studies in human subjects taking folate and/or vitamin $B_{12}$ supplements show that DNA hypomethylation, chromosome breaks, uracil misincorporation and $\mathrm{MN}$ formation are minimised when the plasma concentration of vitamin $B_{12}$ is greater than 300 $\mathrm{pmol} / \mathrm{l}$, plasma folate concentration is greater than 34 $\mathrm{nmol} / \mathrm{l}$, erythrocyte folate concentration is greater than 700 nmol folate/l and plasma homocysteine is less than 7.5 $\mu \mathrm{mol} / 1$ (Everson et al. 1988; Cravo et al. 1994; Blount \& Ames, 1995; Blount et al. 1997; Fenech et al. 1998; Jacob et al. 1998; Titenko-Holland et al. 1998). These concentrations are best achieved at intake levels in excess of current RDA, i.e. more than $400 \mu \mathrm{g}$ folic acid/d and more than 2 $\mu \mathrm{g}$ vitamin $\mathrm{B}_{12} / \mathrm{d}$. It is relevant to point out that epidemiological studies on diet and colorectal or breast cancer suggest that intake greater than $400 \mu \mathrm{g}$ folate/d may be required to minimise cancer risk (Zhang et al. 1999; Giovannucci, 2002), yet recent intake data indicate that less than $25 \%$ Americans met this intake level before 1998, when folate fortification became mandatory in the USA 
(Ames \& Wakimoto, 2002). The most recent data (analysed from CSIRO 1999 National Nutrition Survey; S Record, unpublished data) for Australians indicate that more than 85 $\%$ had intake levels below $400 \mu \mathrm{g}$ folate/d in 1998 and in Holland more than $50 \%$ of the population were below this optimum intake before 1998 (Konings et al. 2001). Dietary intakes above the current RDA may be particularly important in those with extreme defects in the absorption and metabolism of these vitamins, for which ageing is a contributing factor. The above findings suggest that both controlled in vitro experiments and placebo-controlled in vivo interventions are informative in determining optimal micronutrient intake for prevention of genomic instability.

Our current stage of knowledge on the role of micronutrients in maintenance of genomic stability has been recently reviewed in a special issue of Mutation Research (Fenech \& Ferguson, 2001). These reviews identify the current gaps in our knowledge and provide the basic information for appropriate design of both in vitro studies with normal human cells (Fig. 7) and placebo-controlled intervention trials (Fig. 8). These studies are needed to define optimal tissue concentration and determine RDA for genomic stability. In the future, clinical trials with a wide array of complementary DNA damage end-points would be necessary including measures of mitochondrial DNA deletions and point mutations, nuclear microdeletions and point mutations, telomere shortening, balanced chromosomal translocations, chromosome non-disjunction or aneuploidy, MN formation, single- and double-strand breaks in DNA, DNA adducts and microsatellite instability. It is clear that this objective requires multiple expertise. That there is a need for an international collaborative effort to establish RDA for genomic stability is evident.

\section{Nutritional genomics of genome stability}

Perhaps a more useful approach would take into consideration the genotype of individuals with a focus on common genetic polymorphisms that alter the bioavailability of specific micronutrients, their metabolism and the affinity of key enzymes involved in DNA metabolism for their micronutrient cofactor. Supplementation of the diet with appropriate minerals and vitamins could, in some cases, help overcome inherited metabolic blocks in key DNA maintenance pathways (Ames et al. 2002). The latter is expected to be particularly effective when a mutation (polymorphism) in a gene decreases the binding affinity for its cofactor resulting in a lower reaction rate. The interaction between genotype and diet in modulating risk is emerging as an exciting area of research as regards micronutrient effects on DNA. This is illustrated by recent research on the common mutations in the methylene tetrahydrofolate reductase (MTHFR) gene and other genes in the folate-methionine cycle with regard to developmental defects and cancer risk (Skibola et al. 1999, 2002; Brody et al. 2002). The product of the MTHFR gene determines the availability of folate for the synthesis of thymidylic acid from deoxyuridylic acid and is predicted to minimise uracil misincorporation into DNA whilst making less methylfolate available for synthesis of $S$-adenosyl methionine, the common methyl donor (Ames, 1999; Fenech, 2001). Epidemiological studies have suggested that
Defining optimal micronutrient concentration for genome stability: in vitro

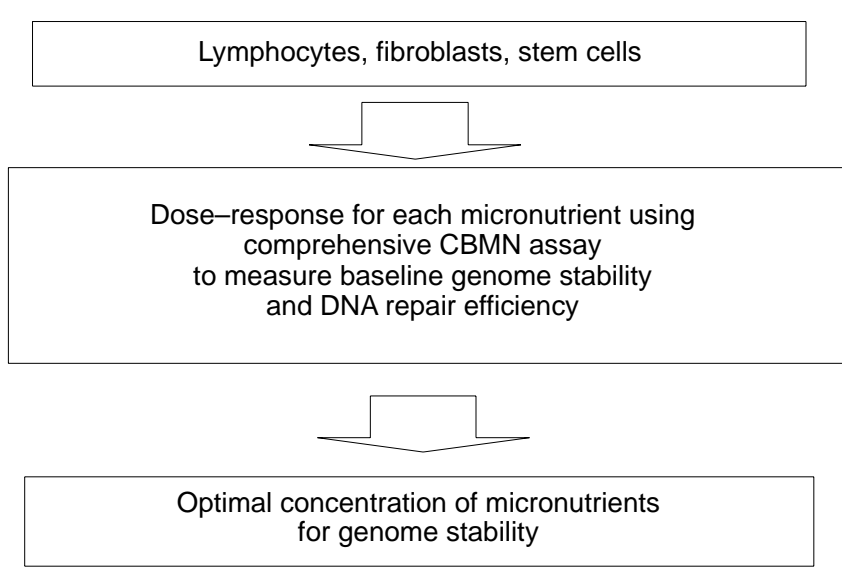

Fig. 7. Schematic diagram of in vitro studies that should be performed to determine optimal micronutrient concentration for genome stability. The cells should be cultured for a minimum of $8 \mathrm{~d}$ in chemically defined culture medium (ideally without serum which varies greatly in composition and may contain traces of the micronutrient under investigation even after dialysis or chelation). A culture time greater than $6 \mathrm{~d}$ is required to observe the effects of micronutrient deficiency in vitro. A dose-response study is essential to define not only the optimal concentration range for genome stability but also to determine the concentration when excess of the micronutrient induces cytotoxicity. CBMN assay, cytokinesisblocked micronucleus assay.

\section{Defining RDA for genome stability: in vivo}

1. Identify high-risk population (i.e. individuals with a high DNA damage rate and/or who are DNA repair-deficient)

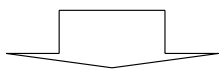

2. Placebo -controlled intervention with increasing doses over an extended period of time depending on the turn over rate of the tissue examined (for example, 3 weeks for buccal cells)

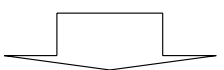

3. Assay genome damage using complementary DNA damage biomarkers to identify dose of micronutrient at which optimal genome stability is achieved

Fig. 8. Schematic diagram for intervention studies required to define the optimal dietary intake of a particular micronutrient for genome stability. Ideally more than one cell type is sampled for analysis to verify that an optimum is achieved for more than one cell type. A combination of the micronucleus assay with other molecular and cytogenetic biomarkers of genome stability such as telomere shortening, DNA oxidation, DNA hypomethylation and aneuploidy of specific chromosomes (for example, chromosomes 17 and 21) and/or chromosomal regions (for example, loss of the $p$ arm of chromosome 17 which includes the p53 gene) associated with increased cancer risk are recommended. RDA, recommended dietary allowances. 
individuals with this genotype may be protected against colorectal cancer and acute lymphocytic leukaemia (Chen et al. 1999; Skibola et al. 1999). Recent results from our laboratory have shown that there are important significant interactions between the MTHFR C677T polymorphism, its cofactor riboflavin and folic acid with regard to chromosomal instability ( $\mathrm{M}$ Kimura, $\mathrm{K}$ Umegaki, M Higuchi, $\mathrm{P}$ Thomas and M Fenech, unpublished results). This is illustrated by: (a) the reduction in nuclear bud frequency in T677T homozygotes relative to $\mathrm{C} 677 \mathrm{C}$ homozygotes; (b) the observation that high riboflavin concentration increases nuclear bud frequency under low folic acid conditions probably by increasing MTHFR activity, which diverts folate away from deoxythymidine triphosphate synthesis, increasing the odds for uracil incorporation into DNA synthesis, the generation of BFB cycles and subsequent gene amplification and nuclear bud formation (Fig. 9). Other common polymorphisms, such as the manganese superoxide dismutase alanine to valine change in the -9 position, which disables transport of this enzyme to the mitochondrion where it is normally located (Ambrasone et al. 1999), increases susceptibility to oxidative stress and breast cancer risk. Individuals with this mutation appear to benefit more than controls from a higher intake of fruit and vegetables and/or vitamin $\mathrm{C}$ in terms of protection against breast cancer (Ambrosone et al. 1999). In the past, considerable attention has been given to gene-environment interactions as they relate to mutagen or carcinogen exposure and genotoxic and/or cancer risk. Fig. 10 illustrates the concept that perhaps the gene-diet interaction as it relates to efficacy of DNA repair and DNA metabolism and micronutrient deficiency may be equally important in determining genomic stability and its consequent impact on fertility, development, cancer risk and the rate of ageing (Ames, 1998, 1999; Chen et al. 1999; Skibola et al. 1999; Trkova et al. 2000).

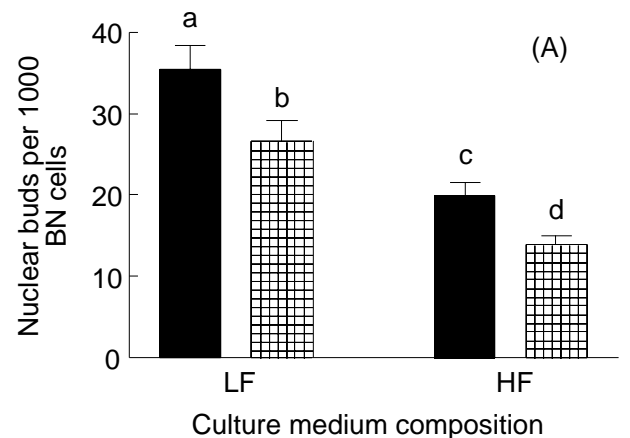

\section{Conclusion: a paradigm shift in disease prevention based on the diagnosis and nutritional treatment of genome damage}

The technological advances described earlier (pp. 111-116) have opened up a new opportunity in disease prevention based on the concepts that: (a) excessive genome instability, a fundamental cause of disease, is often an indication of micronutrient deficiency and is therefore preventable; (b) accurate diagnosis of genome instability using DNA damage biomarkers that are sensitive to micronutrient deficiency is technically feasible; (c) it should be possible to optimise nutritional status and verify efficacy by diagnosis of a reduction in genome damage rate after intervention. Given the emerging evidence that the dietary requirement of an individual may depend on their inherited genes, we can anticipate: (a) important scientific developments in the understanding of the relationships between dietary requirement and genetic background to optimise genome stability; (b) that the accumulated knowledge on dietary requirements for specific genotypes will be used to guide decisions by the practitioners of this novel preventive medicine in what might be called 'Genome Health Clinics'. In other words, one can envisage that instead of diagnosing and treating diseases caused by genome damage, health and medical practitioners will be trained to diagnose and nutritionally prevent the initiating cause, i.e. genome instability itself. This also opens up the possibility for the massive numbers of health-conscious consumers to be able to assess directly the effect of their dietary and nutritional supplement choices on their genome and that of their children. The conceptual framework of the diagnostics and databases required to implement this complementary preventive medicine approach is illustrated in Fig. 11.

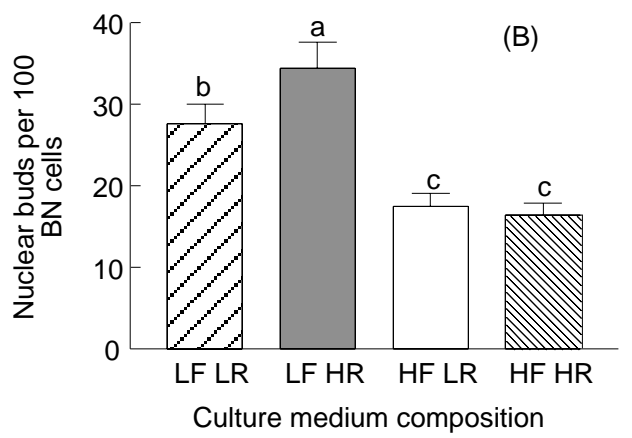

Fig. 9. Nutritional genomics of genome stability illustrated by results from a recent gene amplification experiment from our laboratory using long-term cultured lymphocytes from individuals with either the C677C ( $\square$ ) or the T677T (团) genotype for the methylenetetrahydrofolate reductase (MTHFR) gene. (A), The results of this study show a significant reduction of nuclear bud formation under both low folate (LF; 12 $\mathrm{nmol}$ folic acid/l) and high folate (HF; $120 \mathrm{nmol}$ folic acid/l) conditions for the T677T genotype relative to $\mathrm{C} 677 \mathrm{C}$ and a much reduced nuclear bud frequency in the HF medium relative to the LF medium. Values are means, with standard errors of the mean represented by vertical bars. Two-way ANOVA results were: effect of folate concentration, $P<0.0001$; effect of genotype, $P=0.006$. (B), Interaction of folic acid and riboflavin in determining genome stability $(P<0.0001$ by ANOVA). Specifically the results show that when folic concentration is low $(12 \mathrm{nmol} / \mathrm{l})$, a high concentration of riboflavin ( $500 \mathrm{nmol} / \mathrm{l})$, an essential cofactor for MTHFR, increases genome instability (in this case gene amplification). This effect could be due to an increase in MTHFR activity which may divert folate away from thymidylate synthesis and therefore cause uracil incorporation in DNA which leads to chromosome breakage and gene amplification by the breakage-fusion-bridge cycle mechanism (Fenech, 2002). Values are means, with standard errors of the mean represented by vertical bars. ${ }^{a, b, c, d}$ Mean values with unlike superscript letters were significantly different $(P<0.05$; Tukey's post-hoc test). BN, binucleated; LF LR, $12 \mathrm{nmol}$ folic acid and $0 \mathrm{nmol}$ riboflavin/l; LF HR, $12 \mathrm{nmol}$ folic acid and $500 \mathrm{nmol}$ riboflavin/l; HF LR, $120 \mathrm{nmol}$ folic acid and $0 \mathrm{nmol}$ riboflavin/l; HF HR, $120 \mathrm{nmol}$ folic acid and $500 \mathrm{nmol}$ riboflavin/l. (M Kimura, K Umegaki, M Higuchi, P Thomas and M Fenech, unpublished results.) 


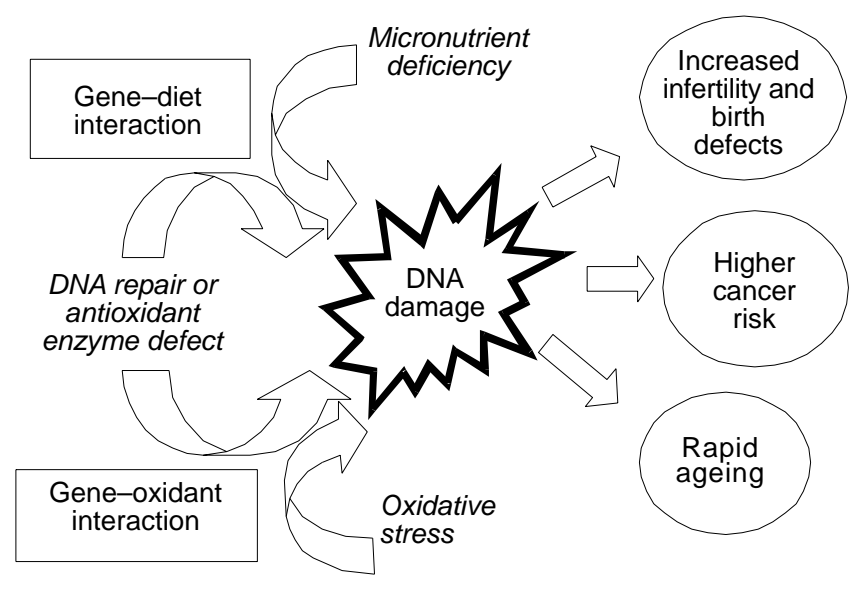

Fig. 10. The concepts of gene-diet and gene-toxin (for example, oxidative stress) interaction and their impact on genome damage and consequent health outcomes.

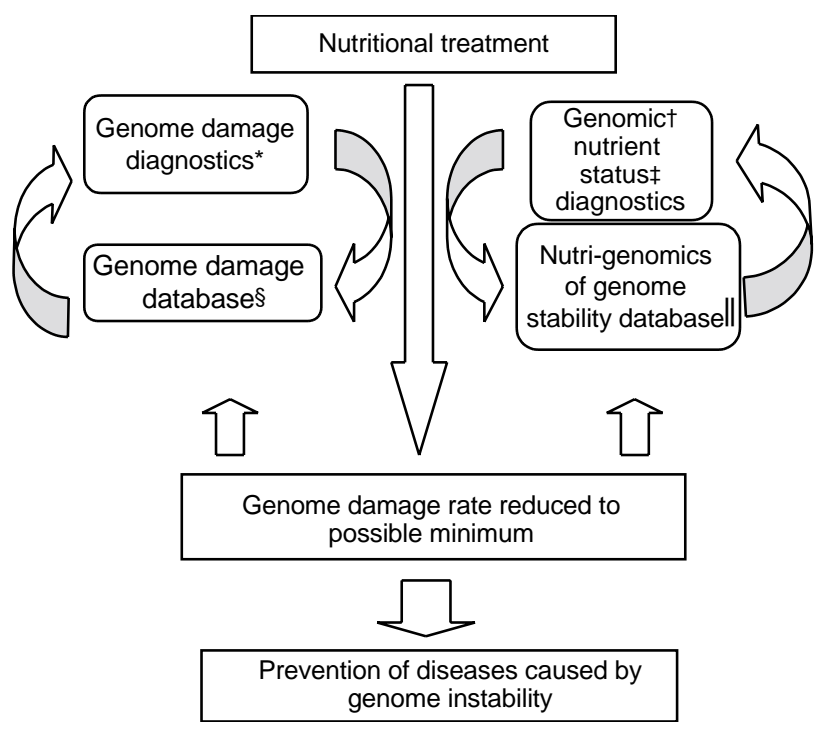

Fig. 11. Conceptual framework of the diagnostics and databases that will be required to implement the novel complementary preventive medicine discipline of nutritional treatment of genome instability, i.e. 'Genome Health Clinics'. * Genome damage diagnostics may include generic chromosomal damage biomarkers (for example, micronucleus assay) as well as genetic anomalies specific to unique disease states (for example, chromosome 17 and 21 aneuploidy or deletions of unique genes such as p53). † Genomics assays would include single nucleotide polymorphisms with reduced affinity of cofactors involved in genome stability maintenance as well as assessment of gene silencing and expression. $\ddagger$ Micronutrients essential for genome stability would be measured (for example, folate, $\mathrm{Zn}$ etc.). $\S$ The genome damage database would include 'normal range' and 'optimal range' values and be used to determine whether an individual's genome damage rate is suboptimal or optimal. || The nutri-genomics database would accrue data on the genome stability response to micronutrient treatment in relation to genetic background and be developed as an expert system to guide future diagnostics and treatments.

\section{Acknowledgements}

The contribution of numerous volunteers, students, postdoctoral fellows, visiting scientists and technical staff to the research performed in our laboratory over many years is gratefully appreciated. Sally Record is gratefully acknowledged for her analysis of folate intake data from the CSIRO 1999 National Nutrition Survey. Aspects of this research were funded by the Cancer Council of South Australia.

\section{References}

Abramsson-Zetterberg L, Zetterberg G, Bergqvist M \& Grawe J (2000) Human cytogenetic biomonitoring using flow-cytometric analysis of micronuclei in transferrin-positive immature peripheral blood reticulocytes. Environmental and Molecular Mutagenesis 36, 22-31.

Ambrosone CB, Freudenheim JL, Thompson PA, Bowman E, Vena JE, Marshall JR, Graham S, Laughlin R, Nemoto T \& Shields PG (1999) Managanese superoxide dismutase (MnSOD) genetic polymorphisms, dietary antioxidants and risk of breast cancer. Cancer Research 59, 602-606.

Ames BN (1998) Micronutrients prevent cancer and delay ageing. Toxicology Letters 102-103, 5-18.

Ames BN (1999) Cancer prevention and diet: help from single nucleotide polymorphisms. Proceedings of the National Academy of Sciences USA 96, 12216-12218.

Ames BN (2001) DNA damage from micronutrient deficiencies is likely to be a major cause of cancer. Mutation Research 475, 7-20.

Ames BN, Elson-Schwab I \& Silver EA (2002) High dose vitamin therapy stimulates variant enzymes with deceased co-enzyme binding affinity (increased $\mathrm{K}(\mathrm{m})$ ): relevance to genetic disease and polymorphisms. American Journal of Clinical Nutrition 75, 616-658.

Ames BN \& Wakimoto P (2002) Are vitamin and mineral deficiencies a major cancer risk? Nature Reviews. Cancer 2, 694-704.

Baria K, Warren C, Eden OB, Roberts SA, West CM \& Scott D (2002) Chromosomal radiosensitivity in young cancer patients: possible evidence of genetic predisposition. International Journal of Radiation Biology 78, 341-346.

Biedler JL \& Spengler BA (1976) Metaphase chromosome anomaly: association with drug resistance and cell-specific products. Science 191, 185-187.

Blount BC \& Ames BN (1995) DNA damage in folate deficiency. Baillere's Clinical Haematology 8, 461-478.

Blount BC, Mack MM, Wehr CM, MacGregor JT, Hiatt RA, Wang G, Wickramasinghe SN, Everson RB \& Ames BN (1997) Folate deficiency causes uracil misincorporation into human DNA and chromosome breakage: implications for cancer and neuronal damage. Proceedings of the National Academy of Sciences USA 94, 3290-3295.

Bonassi S, Fenech M, Lando C, Lin YP, Ceppi M, Chang WP, Holland N, Kirsch-Volders M, Zeiger E, Ban SY, Barale R, Bigatti MP et al. (2001) HUman MicroNucleus Project: International data base comparison for results with the cytokinesis-block micronucleus assay in human lymphocytes: I effect of laboratory protocol, scoring criteria and host factors on the frequency of micronuclei. Environmental and Molecular Mutagenesis 37, 31-45.

Bonassi S, Hagmar L, Stromberg U, Montagud AH, Tinnerberg H, Forni A, Heikkila P, Wanders S, Wilhardt P, Hansteen IL, Knudsen LE \& Norrpa H (2000) Chromosomal aberrations in lymphocytes predict human cancer independently of exposure to carcinogens. Cancer Research 60, 1619-1625.

Boveri M (1929) The Origin of Malignant Tumours. Baltimore, MD: Waverley Press. 
Brison O (1993) Gene amplification and tumor progression. Biochimica et Biophysica Acta 1155, 25-41.

Brody LC, Conley M, Cox C, Kirke PN, McKeever MP, Mills JL, Molloy AM, O'Leary VB, Parle-McDermott A, Scott JM \& Swanson DA (2002) A Polymorphism, R653Q, in the trifunctional enzyme methylenetetrahydrofolate dehydrogenase/ methenyltetrahydrofolate cyclohydrolase/formyltetrahydrofolate synthetase is a maternal genetic risk factor for neural tube defects: Report of the Birth Defects Research Group. American Journal of Human Genetics 71, 1207-1215.

Centers for Disease Control (1992) Recommendations for the use of folic acid to reduce the number of cases of spina bifida and other neural tube defects. Morbidity and Mortality Weekly Report 41, 1-7.

Chen J, Giovannucci EL \& Hunter DJ (1999) MTHFR polymorphisms, methyl-replete diets and risk of colorectal carcinoma and adenoma among U.S. men and women: an example of gene-environment interactions in colorectal tumorigenesis. Journal of Nutrition 129, 560S-564S.

Claycombe KJ \& Meydani SN (2001) Vitamin E and genomic stability. Mutation Research 475, 37-44.

Coquelle A, Pipiras E, Toledo F, Buttin G \& Debattisse M (1997) Expression of fragile sites triggers intrachromosomal mammalian gene amplification and sets boundaries to early amplicons. Cell 89 215-225.

Cravo M, Fidalgo P, Pereira AD, Gouveia-Oliviera A, Chaves P, Selhub J, Mason JB, Mira FC \& Leitao CN (1994) DNA methylation as an intermediate biomarker in colorectal cancer: modulation by folic acid supplementation. European Journal of Cancer Prevention 3, 473-479.

Crott JW \& Fenech M (1999) Effect of vitamin C supplementation on chromosome damage, apoptosis and necrosis ex vivo. Carcinogenesis 20, 1035-1041.

Crott JW, Mashiyama ST, Ames BN \& Fenech M (2001a) Methylenetetrahydrofolate reductase C677T polymorphism does not alter folic acid deficiency-induced uracil incorporation into primary human lymphocyte DNA in vitro. Carcinogenesis 22, 1019-1025.

Crott JW, Mashiyama ST, Ames BN \& Fenech M (2001b) Folic acid deficiency increases chromosome breakage and rearrangement, gene amplification and DNA-uracil content in human lymphocytes in vitro: effect of MTHFR C677T polymorphism. Cancer Epidemiology, Biomarkers and Prevention 10, 1089-1096.

Cruz Suarez R, Gustafsson M \& Mrabit K (2001) IAEA Occupational Radiation Protection Programme. Radiat Prot Dosimetry 96, 17-20.

Dreosti IE (2001) Zinc and the gene. Mutation Research 475, 161-168.

Duesberg P, Stindl R \& Helmann R (2000) Explaining high mutation rates of cancer cells to drug and multidrug resistance by chromosome reassortments that are catalysed by aneuploidy. Proceedings of the National Academy of Sciences USA 97, 14295-14300.

Duthie SJ \& Hawdon A (1998) DNA instability (strand breakage, uracil misincorporation, and defective repair) is increased by folic acid depletion in human lymphocytes in vitro. FASEB Journal 12, 1491-1497.

Everson RB, Wehr CM, Erexson GL \& MacGregor JT (1988) Association of marginal folate depletion with increased human chromosomal damage in vivo: demonstration by analysis of micronucleated erythrocytes. Journal of the National Cancer Institute 80, 525-529.

Fenech M (2000) The in vitro micronucleus technique. Mutation Research 455, 81-95.

Fenech M (2001) The role of folic acid and vitamin B12 in genomic stability of human cells. Mutation Research 475, 57-68.

Fenech M (2002) Chromosomal biomarkers of genomic instability relevant to cancer. Drug Discovery Today 7, 1128-1137.
Fenech M, Aitken C \& Rinaldi J (1998) Folate, vitamin B12, homocysteine status and DNA damage in young Australian adults. Carcinogenesis 19, 1163-1171.

Fenech M, Dreosti I \& Aitken C (1997a) Vitamin-E supplements and their effect on Vitamin-E status in blood and genetic damage rate in peripheral blood lymphocytes. Carcinogenesis $\mathbf{1 8}$, 359-364.

Fenech M, Dreosti IE \& Rinaldi JR (1997b) Folate, vitamin B12, homocysteine status and chromosome damage rate in lymphocytes of older men. Carcinogenesis 18, 1329-1336.

Fenech M \& Ferguson LR (editors) (2001) Micronutrients and genomic stability. Mutation Research 475, 1-6.

Fenech M, Holland N, Chang WP, Zeiger E \& Bonassi S (1999) The HUman MicroNucleus project - an international collaborative study on the use of the micronucleus technique for measuring DNA damage in humans. Mutation Research 428, 271-283.

Fenech M \& Morley AA (1986) Cytokinesis-block micronucleus method in human lymphocytes: effects of in vivo ageing and low dose X-irradiation. Mutation Research 161, 193-198.

Fenech M \& Rinaldi J (1995) A comparison of lymphocyte micronuclei and plasma micronutrients in vegetarians and nonvegetarians. Carcinogenesis 16, 223-230.

Fraga CG, Motchnik PA, Shigenaga MK, Helbock HJ, Jacob RA \& Ames BN (1991) Ascorbic acid protects against endogenous oxidative DNA damage in human sperm. Proceedings of the National Academy of Sciences USA 88, 11003-11006.

Gaziev AI, Sologub GR, Fomenko LA, Zaichkina SI, Kosyakova NI \& Bradbury RJ (1996) Effect of vitamin-antioxidant micronutrients on the frequency of spontaneous and in vitro gamma-ray-induced micronuclei in lymphocytes of donors: the age factor. Carcinogenesis 17, 493-499.

Giovannucci E (2002) Epidemiological studies of folate and colorectal neoplasia: a review. Journal of Nutrition 132, 2350s-2355s.

Gisselson D, Bjork J, Hoglund M, Mertens F, Dal Cin P, Akerman M \& Mandahl N (2001) Abnormal nuclear shape in solid tumours reflects mitotic instability. American Journal of Pathology 158, 199-206.

Green NS (2002) Folic acid supplementation and prevention of birth defects. Journal of Nutrition 132, Suppl., 2356S-2360S.

Griffin CS (2002) Aneuploidy, centrosome activity and chromosome instability in cells deficient in homologous recombination repair. Mutation Research 504, 149-155.

Griffin CS, Simpson PJ, Wilson CR \& Thacker J (2000) Mammalian recombination-repair genes XRCC2 and XRCC3 promote correct chromosome segregation. Nature Cell Biology 2, 757-761.

Hageman GJ \& Stierum RH (2001) Niacin, poly(ADP-ribose) polymerase-1 and genoic stability. Mutation Research 475, $45-56$.

Halliwell B (2001) Vitamin C and genomic stability. Mutation Research 475, 29-35.

Hartwig A (2001) Role of magnesium in genomic stability. Mutation Research 475, 113-121.

Ho E \& Ames BN (2002) Low intracellular zinc induces oxidative DNA damage, disrupts p53, NfkappaB and AP1 binding and affects DNA repair in a rat glioma cell line. Proceedings of the National Academy of Sciences USA 99, 16770-16775.

Holliday R (1995) Understanding Ageing. Cambridge, UK: Cambridge University Press.

Honma M, Tadokoro S, Sakamoto H, Tanabe H, Sugimoto M, Furuichi Y, Satoh T, Sofuni T, Goto M \& Hayashi M (2002) Chromosomal instability in B-lymphoblasotoid cell lines from Werner and Bloom syndrome patients. Mutation Research 520, $15-24$.

Hsia KT, Millar MR, King S, Selfridge J, Redhead NJ, Melton DW \& Saunders PT (2003) DNA repair gene Ercc1 is essential 
for normal spermatogenesis and oogenesis and for functional integrity of germ cell DNA in the mouse. Development 130, 369-378.

Jacky PB, Beek B \& Sutherland GR (1983) Fragile sites in chromosomes: possible model for the study of spontaneous chromosome breakage. Science 220, 69-70.

Jacob RA, Gretz DM, Taylor PC, James SJ, Pogribny IP, Miller BJ, Henning SM \& Swendseid ME (1998) Moderate folate depletion increases plasma homocysteine and decreases lymphocyte DNA methylation in postmenopausal women. Journal of Nutrition 128, 1204-1212.

Joenje H \& Patel JK (2001) The emerging genetic and molecular basis of Fanconi anaemia. Nature Reviews. Genetics 2, 446-457.

Kassie F, Darroudi F, Kundi M, Schulte-Hermann R \& Knasmuller S (2001) Khat (Catha edulis) consumption causes genotoxic effects in humans. International Journal of Cancer 92, 329-332.

Keen CL \& Zidenberg-Cherr S (1996) Manganese. In Present Knowledge in Nutrition, 7th ed., pp. 334-343 [EE Zeigler and LJ Filer, editors]. Washington, DC: ILSI Press.

Konings EJ, Roomans HH, Dorant E, Goldbohm RA, Saris WH \& van den Brandt PA (2001) Folate intake of the Dutch population according to newly established liquid chromatography data for foods. American Journal of Clinical Nutrition 73, 765-776.

Kuramoto K, Ban S, Oda K, Kimura A \& Suzuki G (2002) Chromosomal instability and radiosensitivity in myelodysplastic syndrome. Leukemia 16, 2253-2258.

Lansdorp PM (2000) Repair of telomeric DNA prior to replicative senescence. Mechanisms of Ageing and Development 118, 23-34.

Lessin LS \& Bessis M (1972) Morphology of the erythron. In Hematology, pp. 62-93 [WJ Williams, E Beutler, EJ Erslev and RW Rundles, editors]. New York, NY: Mcgraw-Hill.

Li RH, Sonik A, Stindl R, Rasnick D \& Duesberg P (2000) Aneuploidy vs gene mutation hypothesis of cancer: recent study claims mutation but is found to support aneuploidy. Proceedings of the National Academy of Sciences USA 97, 3236-3241.

Lindahl T \& Wood RD (1999) Quality control by DNA repair. Science 286, 1897-1905.

Liu L, Blasco M, Trimarchi J \& Keefe D (2002) An essential role for functional telomeres in mouse germ cells during fertilization and early development. Developmental Biology 249, 74-84.

Ma C, Martin S, Trask B \& Hamlin JL (1993) Sister chromatid fusion initiates amplification of the dihydrofolate reductase gene in Chinese hamster cells. Genes and Development 7, 605-620.

McClintock B (1942) The fusion of broken ends of chromosomes following nuclear fusion. Proceedings of the National Academy of Sciences USA, 28, 458-463.

MacGregor JT (1990) Dietary factors affecting spontaneous chromosomal damage in man. Progress in Clinical and Biological Research 347, 139-153.

MacGregor JT, Schlegel R, Wehr CM, Alperin P \& Ames BN (1990) Cytogenetic damage induced by folate deficiency in mice is enhanced by caffeine. Proceedings of the National Academy of Sciences USA 87, 9962-9965.

Majer BJ, Laky B, Knasmuller S \& Kassie F (2001) Use of the micronucleus assay with exfoliated cells as a biomarker for monitoring individuals at elevated risk of genetic damage in chemoprevention trials. Mutation Research 489, 147-172.

Melnyk S, Pogribna M, Miller BJ, Basnakian AG, Pogribny IP \& James SJ (1999) Uracil misincorporation, DNA strand breaks, and gene amplification are associated with tumorigenic cell transformation in folic acid deficient/repleted Chinese hamster ovary cells. Cancer Letters 146, 35-44.
Migliore L, Botto N, Scarpato R, Petrozzi L, Cipriani G \& Bonucelli U (1999) Preferential occurrence of chromosome 21 segregation in peripheral blood lymphocytes of Alzheimer disease patients. Cytogenetics and Cell Genetics 87, 41-46.

Migliore L, Scarpato R, Coppede F, Petrozzi L, Bonucelli U \& Rodilla V (2001) Chromosome and oxidative damage biomarkers in lymphocytes of Parkinson's disease patients. International Journal of Hygiene and Environmental Health 204, 61-66.

Moore LE, Warner ML, Smith AH, Kalman D \& Smith MT (1996) Use of the fluorescent micronucleus assay to detect the genotoxic effects of radiation and arsenic exposure in exfoliated human epithelial cells. Environmental and Molecular Mutagenesis 27, 176-84.

Narula A, Kilen S, Ma E, Kroeger J, Goldberg E \& Woodruff TK (2002) Smad4 overexpression causes germ cell ablation and leydig cell hyperplasia in transgenic mice. American Journal of Pathology 161, 1723-1734.

Nathanson KL, Wooster R, Weber BL \& Nathanson KN (2001) Breast cancer genetics: what we know and what we need. Nature Medicine 7, 552-556.

Ng JM, Vrieling H, Sugasawa K, Ooms MP, Grootegoed JA, Vreeburg JT, Visser P, Beems RB, Gorgels TG, Hanaoka F, Hoeijmakers JH \& van der Horst GT (2002) Developmental defects and male sterility in mice lacking the ubiquitin-like DNA repair gene mHR23B. Molecular and Cellular Biology 22, 1233-1245.

O'Brien PJ, Hales BF, Josephy PD, Castonguay A, Yamazoe Y \& Guengerich FP (1996) Chemical carcinogenesis, mutagenesis, and teratogenesis. Canadian Journal of Physiology and Pharmacology 74, 565-571.

Odagiri Y \& Uchida H (1998) Influence of serum micronutrients on the incidence of kinetochore-positive or -negative micronuclei in human peripheral blood lymphocytes. Mutation Research 415, 35-45.

Perry ME, Rolfe M, McIntyre P, Commane M \& Stark GR (1992) Induction of gene amplification by 5-aza-2'-deoxycytidine. Mutation Research 276, 189-197.

Pihan GA, Purohit A, Wallace J, Knecht H, Woda B, Queensberry P \& Doxsey SJ (1998) Centrosome defects and genetic instability in malignant tumours. Cancer Research 58, 3974-3985.

Pihan GA, Purohit A, Wallace J, Malhotra R, Liotta L \& Doxsey SJ (2001) Centrosome defects can account for cellular and genetic changes that characterize prostate cancer progression. Cancer Research 61, 2212-2219.

Piyathilake CJ, Macaluso M, Hine RJ, Vinter DW, Richards EW \& Krumdieck CL (1995) Cigarette smoking, intracellular vitamin deficiency and occurrence of micronuclei in epithelial cells of the buccal mucosa. Cancer Epidemiology, Biomarkers and Prevention 4, 751-758.

Rosin MP \& German J (1985) Evidence for chromosome instability in vivo in Bloom syndrome: increased numbers of micronuclei in exfoliated cells. Human Genetics 71, 187-191.

Rothfus A, Schutz P, Bochum S, Volm T, Eberhardt E, Kreienberg R, Vogel W \& Speit G (2000) Induced micronucleus frequencies in peripheral blood lymphocytes as a screening test for carriers of a BRCA1 mutation in breast cancer families. Cancer Research 60, 390-394.

Saunders WS, Shuster M, Huang X, Gharaibeh B, Enyenihi AK, Petersen I \& Gollin SM (2000) Chromosomal instability and cytoskeletal defects in oral cancer. Proceedings of the National Academy of Sciences USA 97, 303-308.

Scott D, Barber JBP, Levine EL, Burrill W \& Roberts SA (1998) Radiation-induced micronucleus induction in lymphocytes identifies a high frequency of radiosensitivity cases among breast cancer patients: a test for predisposition? British Journal of Cancer 77, 614-620. 
Shen J \& Loeb LA (2001) Unwinding the molecular basis of Werner syndrome. Mechanisms of Ageing and Development 122, 921-944.

Shimizu N, Itoh N, Utiyama H \& Wahl GM (1998) Selective entrapment of extrachromosomally amplified DNA by nuclear budding and micronucleation during $\mathrm{S}$ phase. Journal of Cell Biology 140, 1307-1320.

Shimizu N, Shimuara T \& Tanaka T (2000) Selective elimination of acentric double minutes from cancer cells through the extrusion of micronuclei. Mutation Research 448, 81-90.

Shimura M, Onozuka Y, Yamaguchi T, Hatake K, Takaku F \& Ishizaka Y (1999) Micronuclei formation with chromosome breaks and gene amplification caused by $\mathrm{Vpr}$, an accessory gene of human immunodeficiency virus. Cancer Research 59, 2259-2264.

Skibola CF, Smith MT, Hubbard A, Shane B, Roberts AC, Law GR, Rollinson S, Roman E, Cartwright RA \& Morgan GJ (2002) Polymorphisms in the thymidylate synthase and serine hydroxymethyltransferase genes and risk of adult acute lymphocytic leukemia. Blood 99, 3786-3791.

Skibola CF, Smith MY, Kane E, Roman E, Rollinson S, Cartwright RA \& Morgan G (1999) Polymorphisms in the methylenetetrahydrofolate reductase gene are associated with susceptibility to acute leukaemia in adults. Proceedings of the National Academy of Sciences USA 96, 12810-12815.

Smith DF, MacGregor JT, Hiatt RA, Hooper NK, Wehr CM, Peters B, Goldman LR, Yuan LA, Smith PA \& Becker CE (1990) Micronucleated erythrocytes as an index of cytogenetic damage in humans: demographic and dietary factors associated with micronucleated erythrocytes in splenectomised subjects. Cancer Research 50, 5049-5054.

Stark GR (1993) Regulation and mechanisms of mammalian gene amplification. Advances in Cancer Research 61, 87-113.

Stich HF, Rosin MP \& Vallejera MO (1984) Reduction with vitamin A and beta-carotene administration of proportion of micronucleated buccal mucosal cells in Asian betel nut and tobacco chewers. Lancet 1, 1204-1206.

Thomas P, Umegaki K \& Fenech M (2003) Nucleoplasmic bridges are a sensitive measure of chromosome rearrangement in the cytokinesis-block micronucleus assay. Mutagenesis 18, 187-194.
Thompson JR, Gerald PF, Willoughby ML \& Armstrong BK (2001) Maternal folate supplementation in pregnancy and protection against acute lymphoblastic leukaemia in childhood: a case-control study. Lancet 358, 1935-1940.

Thompson LH \& Schild D (2002) Recombinational DNA repair and human disease. Mutation Research 509, 49-78.

Titenko-Holland N, Jacob RA, Shang N, Balaraman A \& Smith MT (1998) Micronuclei in lymphocytes and exfoliated buccal cells of postmenopausal women with dietary changes in folate. Mutation Research 417, 101-114.

Toledo F, Le Roscouet D, Buttin G \& Debatisse M (1992) Coamplified markers alternate in megabase long inverted repeats and cluster independently in interphase nuclei at early steps of mammalian gene amplification. EMBO Journal 11, 2665-2673.

Trkova M, Kapras J, Bobkova K, Stankova J \& Mejsnarova B (2000) Increased micronuclei frequencies in couples with reproductive failure. Reproductive Toxicology 14, 331-335.

Venkitaraman AR (2002) Cancer susceptibility and the functions of BRCA1 and BRCA2. Cell 108, 171-182.

Vinson RK \& Hales BF (2002) DNA repair during organogenesis. Mutation Research 509, 79-91.

Walter PB, Knutson MD, Paler-Martinez A, Lee S, Xu Y, Viteri FE \& Ames BN (2002) Iron deficiency and iron excess damage mitochondria and mitochondrial DNA in rats. Proceedings of the National Academy of Sciences USA 99, 2264-2269.

Wertz PW \& Squier CA (1991) Cellular and molecular basis of barrier function in oral epithelium. Critical Reviews in Therapeutic Drug Carrier Systems 8, 237-269.

Windle BE \& Wahl GM (1992) Molecular dissection of mammalian gene amplification: new mechanistic insights revealed by analyses of very early events. Mutation Research 276, 199-224.

Yu RC, Lee TC, Wang TC \& Li JH (1999) Genetic toxicity of cocaine. Carcinogenesis 20, 1193-1199.

Zhang S, Hunter DJ, Hankinson SE, Giovannucci EL, Rosner BA, Colditz GA, Speizer FE \& Willett WCA (1999) Prospective study of folate intake and the risk of breast cancer. Journal of the American Medical Association 281, 1632-1637. 